\title{
KRYZYS UKRAIŃSKI - WYZWANIE DLA NATO
}

\author{
Jakub Olchowski \\ Uniwersytet Marii Curie-Skłodowskiej w Lublinie \\ Wydział Politologii, Zakład Stosunków Międzynarodowych \\ adres, email: jakub.olchowski@poczta.umcs.lublin.pl
}

Russia's Ukraine policy is not really about Ukraine. It's really about Europe. The attempt to destabilize Ukraine is part of a larger attempt to destabilize Europe.

T. Snyder

Streszczenie: Artykuł poświęcony jest analizie kryzysu ukraińskiego jako dylematu decyzyjnego, który stanowi wyzwanie dla spójności i wiarygodności NATO. Wyzwanie to warunkowane jest zarówno czynnikami wewnętrznymi (rozbieżność interesów wśród państw członkowskich sojuszu), jak i zewnętrznymi (polityka Rosji, zmierzająca do odzyskania roli mocarstwowej poprzez, między innymi, rozbicie jedności Zachodu). W tym ujęciu Ukraina służy Rosji jako instrument rozgrywki geopolitycznej z Zachodem, dla NATO zaś jest obszarem ryzyka, wymagającym podejmowania strategicznych decyzji.

Słowa kluczowe: NATO, Ukraina, Rosja, ryzyko, proces decyzyjny

\section{WSTĘP}

Organizacja Traktatu Północnoatlantyckiego ${ }^{1}$ jest tzw. klasyczną (koordynacyjną) organizacją międzynarodową. Decyzje przez nią podejmowane są wyrazem woli organizacji jako całości, niemniej de facto organizacja międzynarodowa tego typu uzależniona jest w procesie decyzyjnym od państw członkowskich - ich interesów, potencjałów i woli współpracy. Podejmowanie decyzji jest jednocześnie podstawowym zadaniem organizacji międzynarodowej, umożliwiającym jej

1 Dalej także NATO, Sojusz Północnoatlantycki, sojusz. 
realizację swoich funkcji. ${ }^{2} \mathrm{Im}$ sprawniejszy proces decyzyjny, im większa waga polityczna decyzji, im większy stopień jej realizacji przez państwa członkowskie, tym większa rola, wiarygodność i znaczenie organizacji. Ponadto, decyzje organizacji międzynarodowej muszą uwzględniać zmiany, zachodzące w środowisku międzynarodowym (przy czym należy pamiętać, że z punktu widzenia organizacji jej środowiskiem są także państwa członkowskie) - adaptowanie się do zmian środowiska jest warunkiem sine qua non przetrwania organizacji. W dynamicznym środowisku i przy wielu zmiennych podejmowanie decyzji jest trudniejsze i bardziej ryzykowne w swoich skutkach.

Podczas ponad 65 lat istnienia, Sojusz Północnoatlantycki ewoluował, zmieniając zakres, formy i metody działań, a także strategie. W okresie zimnej wojny sprawdził się jako klasyczny sojusz obronny, mający chronić przed zagrożeniem symetrycznym - żadne państwo członkowskie nie zostało zaatakowane przez inne państwo. Ponadto, spolaryzowany system bezpieczeństwa międzynarodowego ułatwiał określenie ryzyka w wymiarze ilościowym i jakościowym. W realiach pozimnowojennych Sojusz Północnoatlantycki musiał przejść transformację, zredefiniować swoją tożsamość i znaleźć nową formułę działania. Proces ten nadal trwa, ze zmiennym powodzeniem, co determinowane jest przede wszystkim szybko zachodzącymi zmianami środowiska międzynarodowego. W ciągu ostatniego ćwierćwiecza sojusz przyjął nowe państwa członkowskie, pojawiły się nowe kategorie zagrożeń, gwałtowny rozwój technologiczny zmienił oblicze konfliktów zbrojnych, wreszcie zmianie ulega globalny rozkład sił, a tym samym sojuszów, co z kolei wpływa na reorientację polityk bezpieczeństwa państw, w tym państw członkowskich NATO. Dynamika ewolucji środowiska generuje więc szereg kolejnych wyzwań ${ }^{3}$ a tym samym niepewność decyzyjną. Biorąc pod uwagę wysoki poziom skomplikowania obecnej rzeczywistości międzynarodowej i dużą niepewność środowiska poradzieckiego wydaje się, że wybór działań powinien opierać się częściej na metodach stochastycznych niż probabilistycznych. $Z$ drugiej strony przy działaniach o charakterze militarnym da się dość precyzyjnie określić straty tak w ujęciu liczbowym jak i materialnym. Tym samym podjęcie decyzji o zaangażowaniu wojskowym w danym regionie, konflikcie pozwala na zdefiniowanie sytuacji w kategoriach mało-, średnio- lub wysoko ryzykownych.

Można postawić tezę, że polityka Rosji wobec Ukrainy stanowi dla NATO poważny test, swoistą próbę wiarygodności, być może najpoważniejszą od zakończenia zimnej wojny. Dominujące od lat na Zachodzie przeświadczenie, że konwencjonalny, symetryczny konflikt zbrojny w Europie jest niemal nieprawdopodobny, okazało się błędne. W tym kontekście pochopnym okazało się też ograniczanie w wielu państwach, w tym w Polsce, możliwości obronnych sił zbrojnych na rzecz możliwości ekspedycyjnych, związanych z działaniami out

2 W. Morawiecki, Polska nauka o organizacjach międzynarodowych, Warszawa 1993, s. 16.

3 Por. J. Duffield, Sojusze, [w:] Studia bezpieczeństwa, red. P. D. Williams, Kraków 2012, s. $296-300$. 
of area. „Przestawiający się” od kilkunastu co najmniej lat na przeciwdziałanie zagrożeniom asymetrycznym Sojusz Północnoatlantycki nie potrafi znaleźć antidotum na strategię Rosji, łączącą instrumenty militarne i niemilitarne i realizowaną konsekwentnie, mimo rosnących problemów wewnętrznych, politykę zmierzającą do odzyskania przez Rosję pozycji globalnego gracza. Tym samym próby uczynienia z Rosji jeśli nie sojusznika, to partnera Zachodu, zakończyły się fiaskiem, a współpraca instytucjonalna NATO-Rosja w istocie została zamrożona - z nikłymi szansami na jej restytucję w przewidywalnej przyszłości. ${ }^{4}$ Otwarcie konfrontacyjna postawa Rosji jest dla sojuszu nowym jakościowo wyzwaniem, do którego okazał się być nieprzygotowanym.

W działaniach i decyzjach wojskowych, które są podstawą funkcjonowania NATO, ryzyko jest przedsięwzięciem niosącym za sobą straty oraz nieznany wynik. Maciej Marszałek, powołując się na „Leksykon wiedzy wojskowej” podaje trzy rodzaje ryzyka związane $\mathrm{z}$ tą płaszczyzną: strategiczne, operacyjne i taktyczne. Pierwsze z nich dotyczy podjęcia decyzji i/lub działania strategicznego ze świadomością możliwości nieosiągnięcia celów strategicznych i tym samym poniesienia porażki. Drugie obejmuje decyzje lub/i działania głównych sił na poziomie operacyjnym przy braku kompletnej informacji o sytuacji taktyczno-operacyjnej i wkalkulowaniu owej niepewności w realizację zadań i ze świadomością klęski. Natomiast ryzyko taktyczne odzwierciedla takie sam rodzaj działań i decyzji tylko na poziomie taktycznym, a więc oddziału lub pododdziału. $^{5}$

Dla NATO, niezależnie od tego, czy zgodnie z Traktatem Północnoatlantyckim skoncentruje się na kolektywnej obronie, czy ewoluować będzie w kierunku organizacji bezpieczeństwa, jest to sytuacja, generująca istotne ryzyko tj., innymi słowy, sytuację niepewności, związanej z własnymi działaniami (decyzjami), ale też z własnymi zaniechaniami (niedecyzjami). ${ }^{6} \mathrm{~W}$ siatce pojęciowej dotyczącej bezpieczeństwa ryzyko to jedno z podstawowych pojęć - podobnie jak wyzwanie, czyli dylemat, przed jakim stoi podmiot (w tym przypadku NATO) w dziedzinie rozwiązywania spraw bezpieczeństwa. ${ }^{7}$ Kryzys ukraiński stanowi dla NATO wyzwanie nie tylko jako konflikt regionalny. W szerszym kontekście jest to test wiarygodności, która ma fundamentalne znaczenie dla polityczno-wojskowego sojuszu obronnego. Utrzymanie wysokiego poziomu wiarygodności wymaga działań, będących następstwem podjętych decyzji politycznych. Decyzje te (i działania) winny dać odpowiedź na kluczowe pytanie - nie, czy NATO będzie,

4 Decyzja ta została podjęta przez sojusz w kwietniu 2014 r. jako „wyraz potępienia” Rosji z powodu pogwałcenia przez nią suwerenności Ukrainy.

5 M. Marszałek, Ryzyko jako kryterium klasyfikacji operacji reagowania kryzysowego NATO, [w:] Ryzyko w zarządzaniu kryzysowym, (red.) P. Sienkiewicz, M. Marszałek, P. Górny, Toruń 2012, s. 45 - 46.

6 Z. J. Pietraś, Decydowanie polityczne, Warszawa-Kraków 1998, s. 53.

7 S. Koziej, Między piektem a rajem. Szare bezpieczeństwo na progu XXI wieku, Toruń 2006, s. 11 . 
ale jakie będzie i na ile wiarygodne - od tego zależy rola, a nawet, w dłuższej perspektywie, przetrwanie organizacji. W złożonym środowisku bezpieczeństwa decyzje takie obarczone są dużym ryzykiem, warunkowanym zarówno czynnikami wewnętrznymi, jak i zewnętrznymi.

\section{DYLEMATY NATO}

Sojusz Północnoatlantycki jest instytucją bezpieczeństwa - ryzyko jest ex definitione wpisane $\mathrm{w}$ jej funkcjonowanie, niemniej eskalacja konfliktu na Ukrainie nastąpiła w czasie, kiedy NATO stanęło w obliczu podjęcia szeregu istotnych decyzji, dotyczących swojej przyszłości, a wynikających z niekorzystnych zmian w środowisku bezpieczeństwa. W wymiarze geograficznym zmiany te dotyczą, przede wszystkim trzech strategicznych obszarów: wzrostu potencjału i wpływów Chin (co niepokoi zwłaszcza Stany Zjednoczone, stąd ich pivot to Asia), niestabilnej i konfliktogennej sytuacji na Bliskim Wschodzie i w Afryce Północnej oraz wzrastającego napięcia na północno-wschodniej flance sojuszu, wynikającego z polityki Rosji, w sposób zdecydowany wzmacniającej swoje wpływy na obszarze poradzieckim. ${ }^{8}$ "Nowe otwarcie” (kolejne) stało się dla NATO koniecznością także dlatego, że w tym czasie zakończono operację w Afganistanie, która okazała się kilkunastoletnim, kosztownym przedsięwzięciem, które bynajmniej nie przyniosło spodziewanych rezultatów. ${ }^{9}$ Dopóki jednak operacja ISAF trwała, to wokół niej koncentrowały się wysiłki członków NATO (a przynajmniej istniało poczucie prowadzenia wspólnej operacji), ale po jej zakończeniu poszczególne państwa członkowskie skierowały swą uwagę na własne priorytety strategiczne w zakresie bezpieczeństwa, jednocześnie pojawił się szereg wątpliwości, dotyczących celowości i zasadności operacji afgańskiej. $\mathrm{W}$ tych warunkach osiągnięcie konsensusu w sprawie przyszłości sojuszu jest poważnym wyzwaniem.

Sytuację komplikuje postawa Rosji wobec Ukrainy, a w istocie wobec Zachodu. Próby budowania zaufania, podejmowane ze zmiennym szczęściem od zakończenia zimnej wojny, ostatecznie nie przyniosły rezultatów. ${ }^{10}$ Kryzys ukraiński potwierdza też pozimnowojenne tendencje w ewolucji bezpieczeństwa - przenikanie się i uzupełnianie niemilitarnego i militarnego wymiaru, a w konsekwencji głęboką zmianę w zakresie instrumentów i metod prowadzenia „działań wojennych”

\footnotetext{
${ }^{8}$ Zob. szerzej A. Michta, 15 lat w NATO. NATO po 2104 roku-jakie priorytety?, „Bezpieczeństwo Narodowe" 2014, nr I, s. 118-121.

${ }^{9}$ Sytuacji w Afganistanie daleko do stabilności, a koncepcja Global War on Terror okazała się fiaskiem - Al-Kaida nie tyle została pokonana, co straciła znaczenie i wpływy na rzecz znacznie bardziej radykalnego i bezwzględnego „Państwa Islamskiego”.

${ }^{10}$ Zob. szerzej: B. Piskorska, Stosunki NATO-Rosja w nowej architekturze bezpieczeństwa w Europie, [w:] NATO w pozimnowojennym środowisku (nie)bezpieczeństwa, red. M. Pietraś, J. Olchowski, Lublin 2011, s. 362-372.
} 
- co z kolei wymusza adaptację do tych zmieniających się warunków. ${ }^{11}$ Percepcja bezpieczeństwa jest także w dużej mierze konstruowana w świadomości decydentów i społeczeństw. Na tym polu Rosja ma zdecydowaną przewagą nad Zachodem (i NATO), prowadząc szeroko zakrojoną, jednolitą, zdecydowaną i spójną politykę informacyjną (jak też dezinformacyjną). NATO z kolei składa się z 28 państw, różniących się położeniem, potencjałem, kulturą strategiczną, priorytetami w zakresie bezpieczeństwa i hierarchią preferencji w dziedzinie ekonomii czy polityki bezpieczeństwa. $W$ istotny sposób utrudnia to wypracowanie jednolitych, spójnych działań sojuszu jako całości - a spójność, jedność i wykonywanie w dobrej wierze wspólnie podjętych decyzji to najważniejszy czynnik, decydujący o sile, roli i wiarygodności organizacji międzynarodowej. Wszelkie podziały i różnice interesów wykorzystuje adwersarz (Rosja), zgodnie z regułami „,wojny hybrydowej" ${ }^{12}$, grając na pogłębienie tych podziałów, tak wewnątrz Unii Europejskiej, jak i NATO. Działania te, w połączeniu z wewnętrznymi problemami instytucji zachodnich (rozbieżność interesów w kontekście bezpieczeństwa energetycznego, kryzys imigracyjny w Europie, rozluźnienie więzi transatlantyckich etc.) przyczyniają się do spadku zaufania do NATO wśród jego członków. A siłą sojuszu jest jedność - zaś jej brak można wykorzystać, przyczyniając się do wywoływania i pogłębiania kryzysu politycznego, np. poprzez podsycanie postaw radykalnych. Stąd wsparcie Rosji dla radykalnych ugrupowań w Europie - od lewicowej Syrizy w Grecji po Front Narodowy we Francji. Innym, skutecznym instrumentem jest, stosowany od lat z powodzeniem, ,nacisk energetyczno-surowcowy” na Europę. Na poziomie oddziaływania na społeczeństwa zachodnie istotne znaczenie ma też szeroko zakrojona ofensywa (dez)informacyjna. W efekcie państwa europejskie, posiadając odmienne interesy i różną percepcję kryzysu ukraińskiego, nie potrafią wypracować jednolitej polityki wobec Rosji. Przekłada się to bezpośrednio na osłabienie zdolności decyzyjnej NATO, która w dużej mierze zależy od spójności politycznej członków sojuszu. Dodatkowo, w zmiennym, dynamicznym środowisku trudno jest podejmować decyzje o charakterze strategicznym i długofalowym - możliwość ich ewentualnego efektywnego korygowania jest ograniczona, szczególnie w przypadku specyficznego ośrodka decyzyjnego, jakim jest organizacja międzynarodowa. Jest to bowiem tzw. decyzja międzynarodowa, wymagająca konsensusu i wspólnego oświadczenia woli określonej liczby (w przypadku NATO aż 28) suwerennych podmiotów. ${ }^{13}$

${ }^{11} \mathrm{Na}$ temat zmieniającej się natury konfliktów zbrojnych zob. szerzej: M. Pietraś, Nowa jakość zbrojnych konfliktów międzynarodowych, [w:] Teoria i praktyka stosunków międzynarodowych. Dziedzictwo intelektualne Profesora Ziemowita Jacka Pietrasia, Lublin 2014, s. 55-68.

${ }^{12}$ Pojęcie „wojna/konflikt hybrydowy” jest nieco nadużywane w ostatnim czasie, niemniej trudno zgodzić się z tymi, którzy twierdzą, że takowe konflikty nie istnieją, a mówić należy np. o „odmianie wojny specjalnej”. Warto tu przypomnieć, że pojęcie „wojna hybrydowa” zostało publicznie użyte przez gen. Walerija Gierasimowa, szefa rosyjskiego Sztabu Generalnego, na początku 2013 r.

${ }^{13}$ Z. J. Pietraś, op. cit., s. 54. 
Stąd też kryzys ukraiński jest wyzwaniem dla NATO. Ryzyko w polityce jest najczęściej związane z podejmowaniem decyzji i ich implementacją przez poszczególne podmioty, a politykę „w obszarze ryzyka można określić jako zespół środków obejmujących antycypowanie, unikanie i kompensowanie ryzyka". ${ }^{14}$ Tymczasem NATO nie tylko nie wie, jak swoją politykę w obszarze ryzyka kształtować (w odniesieniu do kryzysu ukraińskiego i jego konsekwencji dla bezpieczeństwa międzynarodowego), ale nawet, w przypadku podjęcia określonych decyzji, jak skłonić państwa członkowskie do ich implementacji.

\section{CZYNNIKI WEWNĘTRZNE}

Do czynników wewnętrznych, decydujących o wyzwaniu dla wiarygodności sojuszu, jakim jest kryzys ukraiński, zaliczyć trzeba: specyfikę procedury decyzyjnej, niespójność sojuszu (kryzys tożsamości), spadek potencjału militarnego i dylematy związane z dalszym rozszerzaniem organizacji. Specyfika procesu decyzyjnego Sojuszu Północnoatlantyckiego polega na tym, że organizacja posiada tylko jeden, traktatowo umocowany, polityczny organ decyzyjny - Radę Północnoatlantycką. W jej skład wchodzą przedstawiciele państw członkowskich. Podstawową zaś procedurą decyzyjną, choć nie wynika ona wprost z traktatu, jest konsensus. Jedynie w najważniejszych kwestiach, jak przyjęcie nowych członków czy zastosowanie Artykułu 5, obowiązuje zasada jednomyślności. Ponadto, oświadczenia Rady, adresowane do państw trzecich i ogólnie środowiska międzynarodowego, są oficjalnym stanowiskiem NATO w danej sprawie - ustalonym $\mathrm{w}$ istocie przez państwa członkowskie.

Taka procedura decyzyjna powoduje, że NATO posiada niewielką władzę nad państwami członkowskimi, proces decydowania politycznego może trwać długo, a decyzje konsensualne, ex definitione mające charakter kompromisowy stąd mogą mieć charakter dość ogólnikowy. Łatwo też w takiej sytuacji o niepodjęcie decyzji. Tak skonstruowana procedura decyzyjna jest czasochłonna, ponieważ wymaga wypracowania, w drodze konsultacji politycznych, wspólnego stanowiska, będącego wypadkową interesów poszczególnych państw. Może to oznaczać, że podjęta decyzja będzie miała charakter niejednoznaczny bądź warunkowy lub stanie się decyzją symboliczną lub optatywną ${ }^{15}$ Przykładem może być decyzja szczytu NATO, który miał miejsce w Newport w 2014 roku. Zreformowano Siły

${ }^{14}$ T. T. Kaczmarek, 2006, Ryzyko i zarzadzanie ryzykiem. Ujęcie interdyscyplinarne, Warszawa 2006, s. 68.

${ }^{15}$ Decyzja optatywna powstaje w wyniku niemal kompletnego procesu decyzyjnego, jest merytorycznie i proceduralnie prawidłowa, jednak brakuje jej implementacja. Taka decyzja może być uznana również za decyzję symboliczną, kiedy decydenci prawidłowo rozpoznają stan rzeczywistości, określają cele zmian, jednak brak jest metod i środków, które pozwolą na faktyczną zmianę tej rzeczywistości. Patrz szerzej: Z. J. Pietras, Decydowanie polityczne, Warszawa-Kraków 1998, s. 154-155. 
Odpowiedzi NATO (NRF - NATO Response Force), tworząc tzw. szpicę, która ma być zdolna do podjęcia działań w ciągu kilku dni - po pierwsze jest to bardzo kompromisowa decyzja, po drugie użycie tych sił jest uzależnione od decyzji Rady Północnoatlantyckiej, co będzie oznaczało wypracowywanie kolejnego kompromisu, co może być czasochłonne, szczególnie w sytuacji wystąpienia tzw. sytuacji trudnokonsensualnej, tj. dotyczącej np. działań o charakterze hybrydowym (czy stanowią one naruszenie Artykułu 5?). Innym problemem jest kwestia implementacji już podjętej decyzji, czego najlepszym przykładem wspólne zobowiązanie państw członkowskich do przeznaczania $2 \%$ PKB na obronność - zobowiązanie, z którego nie wywiązuje się obecnie 23 na 28 państw członkowskich NATO. Jak wspomniano, podejmowanie decyzji jest dla organizacji międzynarodowej koniecznością, stanowi to rację jej bytu. Oznacza to jednak także podejmowanie ryzyka, zwłaszcza w przypadku decyzji długookresowych, o znaczeniu strategicznym. Sojusz Północnoatlantycki niechętnie podejmuje jednak ryzykowne decyzje. Przyczyną jest, z jednej strony, mechanizm decyzyjny i rozbieżność interesów członków organizacji, z drugiej zaś niebagatelne znaczenie ma deficyt charyzmatycznych przywódców-wizjonerów (mężów stanu) u steru sojuszu. Specyficznym przykładem jest postawa NATO wobec konfliktu w Syrii. Mimo, że trwa on od kilku już lat, sojusz nie podjął praktycznie żadnych działań (pomimo przyjęcia zasady działania out of area), ograniczając się jedynie do okresowego wsparcia Turcji kilkoma bateriami rakiet Patriot w celu ochrony jej granicy. Turcji, której postawa wobec konfliktu syryjskiego i sojuszników z NATO jest co najmniej dwuznaczna.

Kolejnym czynnikiem, destabilizującym funkcjonowanie sojuszu, jest jego niespójność wewnętrzna (i szerzej: problem z jego tożsamością). Stany Zjednoczone skłaniają się, w kontekście kryzysu ukraińskiego, do powstrzymywania Rosji, ale Niemcy, Włochy i Francja raczej naciskają na Ukrainę, by stosowała się do postanowień porozumienia Mińsk II - bez względu na to, że Rosja złamała je natychmiast po podpisaniu. Turcja, jak zaznaczono, pozostaje kłopotliwym sojusznikiem - od początku konfliktu w Syrii zajmuje wobec niego ambiwalentną postawę, konsekwentnie realizując własne interesy, tj. dąży przede wszystkim do wyeliminowania Asada i osłabienia Kurdów, rosnących w siłę na fali sukcesów w walce z „Państwem Islamskim”. W 2015 roku Turcja zaczęła zresztą prowadzić otwarcie wrogie działania wobec Kurdów, co jest sprzeczne z interesami jej zachodnich sojuszników i de facto działa na korzyść „Państwa Islamskiego” - państwa zachodnie nie reagują jednak na to. ${ }^{16}$ Inne państwa z południowej flanki NATO za priorytet uważają zagrożenia w obszarze Morza Śródziemnego - problem tzw. Państwa Islamskiego, niestabilnej sytuacji w Afryce Północnej, imigrantów, piractwa i przestępczości zorganizowanej. Państwa skandynawskie są zaniepokojone aktywnością Rosji, ale raczej w obszarze Arktyki. Działania

${ }^{16}$ Repetowicz, Sz. Ananicz, Dylematy Turcji $w$ wojnie przeciwko Państwu Islamskiemu, „Analizy OSW”, 15.10.2014, http://www.osw.waw.pl, (dostęp: 11.07.2015). 
Rosji w kontekście Ukrainy najwięcej obaw budzą zaś w państwach środkowoeuropejskich, szczególnie nadbałtyckich.

Sojuszowi coraz bardziej brak też zdecydowanego lidera - dla Stanów Zjednoczonych NATO nie jest już tak istotne jak w okresie zimnej wojny, natomiast podzielona Europa, jak pokazują kolejne kryzysowe sytuacje, nie potrafi podjąć zdecydowanych i adekwatnych działań. NATO to wciąż symbol „siły Zachodu”, ale, szczególnie w Europie, nawykłej do braku realnych, bezpośrednich zagrożeń, symbol ten staje się ,papierowym tygrysem”. Ten brak spójności i jednolitego stanowiska w kwestii kluczowych zagrożeń rodzi nieufność wewnątrz sojuszu. Biorąc pod uwagę, że ani memorandum budapeszteńskie, ani normy prawa międzynarodowego nie uchroniły Ukrainy przed pogwałceniem jej integralności terytorialnej, rośnie przeświadczenie, także w państwach członkowskich NATO, że gwarancje międzynarodowe są nieefektywne. Dotyczy to także, skutecznego dotychczas, „parasola ochronnego" NATO. Polityka powstrzymywania w przypadku obecnie przyjętej przez Rosję taktyki okazuje się nieskuteczna, a w samym NATO nie brak głosów, że w przypadku na przykład rosyjskiej agresji na państwa bałtyckie sojusz byłby bezradny. I to właśnie w państwach bałtyckich obawy związane z Rosją są najsilniejsze. Działania Rosji obliczone są na podsycanie tych obaw: latem 2015 roku w Dumie pojawiły się postulaty zbadania legalności uznania w 1991 roku, przez Radę Najwyższą ZSRR, niepodległości państw bałtyckich. Niewiele wcześniej, w czerwcu 2015 roku, Prokuratura Generalna Federacji Rosyjskiej uznała za niekonstytucyjne przekazanie USRR Krymu w 1954 roku. ${ }^{17}$ Także w innych państwach członkowskich, szczególnie Europy Środkowo-Wschodniej, wiara w pomoc militarną sojuszu w przypadku ewentualnej agresji zewnętrznej zmniejsza się.

Prowadzi to do swoistego „rozpadu regionalnego”, od kwietnia 2015 r. zacieśnienie współpracy Norwegii, Danii, Szwecji i Finlandii w ramach NORDEFCO (Nordyckiej Współpracy Obronnej, powołanej w 2009 roku). Polska i państwa bałtyckie, postrzegające postawę Rosji jako rosnące zagrożenie, optują za wzmocnieniem wschodniej flanki sojuszu, np. poprzez utworzenie w państwach środkowoeuropejskich stałych baz NATO. Chcą też zacieśnienia współpracy regionalnej w zakresie obronności - ani jeden, ani drugi postulat nie znajduje w pełni zrozumienia wśród partnerów z sojuszu - w obu przypadkach z powodu rozbieżności interesów poszczególnych państw, przedkładających racjonalność indywidualną nad kolektywną oraz obaw przed „drażnieniem Rosji”. Proces rozwarstwienia sojuszu nie został zainicjowany przez wydarzenia na Ukrainie i politykę Rosji, a jedynie przez nie pogłębiony. Podział w NATO na ,globalistów” (Stany Zjednoczone, Wielka Brytania, Dania, Kanada), „koalicję Artykułu 5” (wschodnia, „,nowa” flanka sojuszu) oraz „,biernych, chwiejnych i milczących” (Włochy, Hiszpania, Niemcy, Grecja, Portugalia) dostrzegany był od dawna. ${ }^{18}$

${ }^{17}$ Е. Фохт, Генпрокуратура признала неконституционной передачу Крыма Украине в 1954 2., http://top.rbc.ru/politics/27/06/2015/, (dostęp 11.07.2015).

${ }^{18}$ K. Libront, Ewolucja tożsamości NATO w XXI wieku, [w:] NATO wobec wyzwań wspótczesnego świata, red. R. Czulda, R. Łoś, J. Reginia-Zacharski, Łódź 2013, s. 59. 
Od zakończenia zimnej wojny znacząco spadł też potencjał militarny sojuszu. Zwłaszcza w europejskich państwach członkowskich NATO systematycznie ograniczano wydatki obronne i liczebność armii - co wynikało z przekonania, że w Europie otwarty międzypaństwowy konflikt zbrojny jest mało prawdopodobny. W efekcie Holandia pozbyła się czołgów, brytyjska Royal Navy nie posiada żadnego pełnowartościowego lotniskowca ani morskich samolotów patrolowych, Niemcy znaczną liczbę czołgów sprzedały bądź przekazały sojusznikom itp. ${ }^{19}$ W niektórych przypadkach prowadzi to do paraliżu podstawowych zdolności obronnych. Zjawisko demilitaryzacji Europy pogłębiło się zwłaszcza w okresie po 2008 roku, który przyniósł pogorszenie sytuacji gospodarczej. Także Stany Zjednoczone, w ramach tzw. sekwestracji, redukują wydatki wojskowe. Obecnie jedynie pięć państw członkowskich stosuje się do zasady (potwierdzonej zresztą explicite podczas szczytu w Newport), dotyczącej przeznaczania na obronność min. $2 \%$ PKB, a jednocześnie systematycznie spada ogólny udział NATO w globalnych wydatkach militarnych. ${ }^{20} \mathrm{Na}$ poziomie sojuszu jako całości przekłada się to m.in. na osłabienie jego możliwości operacyjnych - ze względu na różnice między deklarowaną a rzeczywistą zdolnością poszczególnych państw do udziału w działaniach sojuszniczych. Ponadto, poszczególne państwa prowadzą zróżnicowaną politykę dotyczącą artykułowania i realizowania strategicznych celów w zakresie bezpieczeństwa czy samego prowadzenia polityki obronnej. ${ }^{21}$ Odmienne jest także rozumienie zagrożeń i podejście do użycia siły, co związane jest $\mathrm{z}$ odmienną kulturą strategiczną, zwłaszcza w przypadku różnic między Amerykanami a Europejczykami. W tym kontekście podkreślić należy kolejny problem, dotyczący kształtu relacji transatlantyckich: strategiczne priorytety po obu stronach Atlantyku są coraz bardziej rozbieżne, co osłabia polityczną spoistość sojuszu, a jednocześnie Amerykanie coraz wyraźniej domagają się od europejskich partnerów większego wkładu w rozbudowę i utrzymanie potencjału militarnego sojuszu - wieloletnie zaniedbania Europy w tym względzie osłabiają z kolei spoistość wojskową NATO i pogłębiają tzw. military gap między Stanami Zjednoczonymi a Europą. ${ }^{22}$

${ }^{19} \mathrm{~W}$ pewnym okresie więcej niemieckich czołgów Leopard, służących w linii, posiadało Wojsko Polskie niż Bundeswehra. Obecnie Niemcy, z powodu napiętej sytuacji międzynarodowej, rozważają przywrócenie do służby starszych wersji Leopardów, uprzednio wycofanych.

${ }^{20}$ Nadal jednak łączne wydatki wojskowe NATO stanowią ponad połowę wydatków globalnych. Państwa członkowskie NATO, które przeznaczają min. 2\% PKB na obronność (2014) to: USA, Wlk. Brytania, Grecja, Estonia i Polska. Na podstawie danych NATO z czerwca 2015 r.: http://www.nato.int/nato_static_fl2014/assets/pdf/pdf_2015_06/20150622_PR_CP_2015_093v2.pdf, (dostęp: 11.07.2015).

${ }^{21}$ Przykładem mogą być tzw. białe księgi. We Francji (ale też innych państwach zachodnich) Biała Księga traktowana jest jako zestaw zadań, które należy i trzeba wykonać (w określonym czasie), natomiast w Polsce Biała Księga to jedynie zestaw rekomendacji i zaleceń, w dodatku istniejący równolegle do innych dokumentów „strategicznych”, niejednokrotnie dublujących swoje treści.

${ }^{22}$ Zob. szerzej: R. Czulda, Wyzwanie dla NATO: postępujacy rozłam potencjatów, [w:] NATO wobec wyzwań..., s. 345-351. 
Kolejny problem dotyczy procesu rozszerzania sojuszu. Proces ten uległ zahamowaniu i raczej mało prawdopodobne jest, by ta tendencja uległa odwróceniu. Podczas szczytu NATO w Chicago (2012 r.) kwestia ta została niemal całkowicie pominięta. Hillary Clinton wyraziła wówczas nadzieję, że ,ten szczyt będzie ostatnim szczytem, który nie jest szczytem poszerzającym [Sojusz]"23, ale kolejny szczyt NATO, który odbył się już po aneksji Krymu przez Rosję i po krwawych walkach na wschodzie Ukrainy (Newport, wrzesień 2014 r.), w ogóle nie odniósł się do kwestii ewentualnego rozszerzenia sojuszu - a bez wątpienia jest to kwestia ściśle powiązana z relacjami NATO z Rosją. Trudno oczekiwać, by szczyt NATO w Warszawie, zaplanowany na lipiec 2016 roku, przyniósł jakieś istotne decyzje w tym zakresie. Zwłaszcza, że z punktu widzenia interesów Rosji także jest to jedna z kluczowych kwestii - już jesienią 2014 roku minister Siergiej Ławrow ostrzegł, że akcesja państw bałkańskich do NATO zostanie przez Rosję potraktowana jako ,prowokacja”. ${ }^{24}$

\section{CZYNNIKI ZEWNĘTRZNE}

Wśród zewnętrznych czynników, determinujących funkcjonowanie NATO, wskazać można wiele niekorzystnych zjawisk, generujących wyzwania i zagrożenia. Zaliczyć do nich trzeba kryzys na Bliskim Wschodzie (wojna w Syrii, Państwo Islamskie), zagrożenia asymetryczne (terroryzm, transnarodowa przestępczość zorganizowana), problemy związane $z$ cyberbezpieczeństwem i bezpieczeństwem energetycznym itp. Do rangi jednego z najważniejszych wyzwań, co pokazuje kryzys ukraiński, urosła także w ostatnich latach Rosja, dążąca do rewizji porządku międzynarodowego. Oznacza to dla sojuszu konieczność przeformułowania założeń strategicznych i konieczność dogłębnej analizy obecnej sytuacji i możliwych scenariuszy. Tym samym, jest to konieczność podejmowania decyzji (przy czym, jak wcześniej wspomniano, zaniechanie jest także decyzją, niosącą określone konsekwencje). Relacje NATO i Rosji uległy w ostatnich dwóch latach gwałtownemu pogorszeniu. Dialog amerykańsko-rosyjski został niemal całkowicie wstrzymany, pojawiły się nawet w stosunkach Stanów Zjednoczonych i Rosji wątki ,parazimnowojenne", jak na przykład odrzucenie przez Rosję amerykańskiej propozycji dotyczącej rozbrojenia nuklearnego z 2013 roku, odrzucenie traktatu o konwencjonalnych siłach zbrojnych w Europie (Traktat CFE) czy groźba wycofania się $\mathrm{z}$ traktatu o likwidacji pocisków średniego i pośredniego zasięgu (Traktat INF). Rośnie napięcie w Arktyce, której znaczenie jest coraz większe z powodu zasobów naturalnych, mających z kolei kluczowe znaczenie dla Rosji, opierającej na nich

${ }^{23}$ Cyt. za: A. Michta, op. cit., s. 126.

${ }^{24}$ J. Gedmin, It's Not Just Ukraine, "Politico", 30.11.2014, http://www.politico.com/magazine/story/2014/11/its-not-just-ukraine-113164, (dostęp 11.07.2015). 
swoją gospodarkę. Nie bez znaczenia jest też dla tego wzrostu napięcia fakt, że spośród ośmiu państw arktycznych pięć należy do NATO.

Jednocześnie Rosja sukcesywnie podnosi, w przeciwieństwie do państw NATO i mimo pogarszającej się sytuacji gospodarczej, wydatki wojskowe, modernizując swoje siły zbrojne. W ciągu ostatniej dekady wydatki militarne wzrosły w Rosji, według danych SIPRI, z 3,6\% do 4,5\% PKB. Stawia to Rosję na trzecim miejscu w świecie, po Stanach Zjednoczonych i Chinach, pod względem sum przeznaczanych na cele militarne, a jednocześnie na trzynastym miejscu w grupie 20 państw, które przeznaczają na te cele ponad 4\% PKB (w grupie tej nie ma ani jednego państwa NATO). ${ }^{25}$ W 2014 roku Rosja wydała ok. 85 mld dolarów: w kontekście swojej ekspansji w Arktyce rozwija ,wojska arktyczne”, zdolne do działań w niesprzyjających warunkach klimatycznych; po aneksji Krymu dokonała jego remilitaryzacji, rozbudowując garnizony i rozwijając plany wymiany przestarzałych już w większości okrętów Floty Czarnomorskiej; w Obwodzie Kaliningradzkim rozmieszcza m.in. nowoczesne rakiety Iskander. ${ }^{26}$ Utrzymywanie nuklearnego potencjału, profesjonalizacja sił zbrojnych, rosnący nacisk na cyberwarfare, intensywne prace nad systemami bezzałogowymi, ale także militarne wykorzystanie posiadanych przez Rosję technologii kosmicznych - wszystkie te elementy służyć mają budowie potęgi militarnej Rosji. Militaryzacji gospodarki towarzyszą działania (skuteczne), adresowane do społeczeństwa i mające na celu pobudzenie dumy narodowej, wzmocnienie etosu żołnierza i konsolidację społeczeństwa rosyjskiego wokół władz na Kremlu jako tych, które przywracają Rosji należną jej pozycję i znaczenie. Uzupełnia to intensywna kampania informacyjna, głosząca konieczność obrony przed zachodnią agresją. ${ }^{27}$ Antyzachodnia i antynatowska retoryka nie jest niczym nowym, bowiem już od lat 90 Rosja, różnymi metodami, zmierzała do osłabienia wpływów NATO.

Zbrojeniom i retoryce towarzyszą też ciągłe ćwiczenia wojskowe (od początku 2013 roku niemal nieprzerwane) - ich scenariusz niejednokrotnie wprost dotyczy konfliktu z państwami zachodnimi, a uczestniczą w nich często dziesiątki tysięcy żołnierzy i tysiące jednostek uzbrojenia (dla porównania, w szeroko nagłaśnianych medialnie ćwiczeniach NATO „Steadfast Jazz 2013”, największych manewrach sojuszu od 2006 roku, wzięło udział sześć tysięcy żołnierzy) ${ }^{28}$. Mnożą

${ }^{25}$ Trends in World Military Expenditure, 2014, http://books.sipri.org/files/FS/SIPRIFS1504. pdf, (dostęp: 11.07.2015); por. A. Wilk, Rosyjskie przygotowania do wielkiej wojny?, „Analizy OSW”, 24.09.2014, http://www.osw.waw.pl, (dostęp 11.07.2015). W grupie tej znajdowały się Stany Zjednoczone, które jednak zredukowały swoje wydatki militarne do poziomu poniżej 4\% PKB.

${ }^{26}$ Tylko w roku 2015 rosyjskie siły zbrojne mają otrzymać więcej sprzętu niż Wojsko Polskie w ramach całego planu modernizacji technicznej sił zbrojnych na lata 2013-2022. Nawet uwzględniając proporcje potencjałów obu państw czy też biorąc pod uwagę aspiracje mocarstwowe Rosji jest to znamienna asymetryczność.

${ }^{27}$ Szeroko zakrojone działania dezinformacyjne ze strony Rosji obejmowały m.in. rozpowszechnianie pogłosek o udziale „najemników z NATO” w walkach na wschodzie Ukrainy, np. w czasie obrony lotniska w Doniecku.

${ }^{28}$ Jak zauważył gen. James Stavridis, znany z barwnych wypowiedzi, w ćwiczeniach NATO najistotniejsze znaczenie mają uroczyste zakrapiane bankiety i pamiątkowe plakietki. 
się incydenty w przestrzeni powietrznej i na morzu - ich celem jest „testowanie” NATO (zarówno cierpliwości, jak i zdolności obronnych, systemów elektronicznych, dowodzenia itp.) - na skalę niewyobrażalną jeszcze kilka lat temu - dotyczy to zwłaszcza państw bałtyckich, np. Litwa zarejestrowała w 2014 roku około 150 incydentów z udziałem rosyjskich samolotów (podczas gdy w 2004 roku - cztery), w przypadku Łotwy było to 180 incydentów, ponadto rosyjskie okręty ok. 40 razy znalazły się w łotewskiej wyłącznej strefie ekonomicznej bądź w pobliżu wód terytorialnych Łotwy. Wzmożona aktywność sił rosyjskich budzi obawy także w Szwecji. ${ }^{29}$ Ponadto, regularnie pojawiają się doniesienia (zapewne w dużej mierze o charakterze dezinformacyjnym) o rosyjskich planach otwierania baz wojskowych w różnych częściach globu, mówi się np. o Serbii, Czarnogórze, Egipcie, Algierii, Cyprze, Seszelach, Nikaragui, Wenezueli. Mimo, że doniesienia te są dementowane, wywołują zamierzony efekt propagandowy. Decyzja Rosji o wysłaniu sił zbrojnych do Syrii także ma zademonstrować gotowość Rosji do podejmowania zdecydowanych działań, również militarnych, w celu realizacji swoich interesów geopolitycznych i aktywnego wpływania na kształt ładu międzynarodowego. Jednocześnie uwypukla to niezdecydowanie NATO i, szerzej, Zachodu, który, szczególnie od czasu operacji libijskiej, hołduje zasadzie no boots on the ground ${ }^{30} \mathrm{i}$ ogranicza się głównie do operacji powietrznych.

Z punktu widzenia teoretycznych koncepcji bezpieczeństwa obecna, ekspansywna polityka Rosji charakterystyczna jest dla jednego z nurtów realizmu, tj. realizmu ofensywnego. Nurt ten zakłada, że warunkiem zapewnienia sobie przez państwo bezpieczeństwa jest maksymalizacja potęgi. Jeden z głównych teoretyków tego nurtu, John Mearsheimer, twierdzi, że najpewniejszym sposobem zapewnienia sobie przetrwania jest zakumulowanie potęgi większej niż inni, nawet jeśli wymaga to podejmowania istotnego ryzyka - w efekcie państwo działa ofensywnie, kierując się defensywnymi przesłankami. ${ }^{31}$ Perspektywa realistyczna wyjaśnia zarówno stosunek Rosji do NATO, jak i przyczyny słabości NATO w obecnej konfrontacji z Rosją. Po pierwsze, zgodnie z założeniami realistów organizacje międzynarodowe są jedynie instrumentami polityki państw wobec innych państw. Z punktu widzenia Rosji NATO było i jest instrumentem realizacji interesów Stanów Zjednoczonych, a zatem budowania ładu międzynarodowego, opartego (w percepcji

${ }^{29}$ E. Braw, Bully in the Baltics: The Kremlin's Provocations, http://www.worldaffairsjournal. org/article/bully-baltics-kremlin\%E2\%80\%99s-provocations, (dostęp: 01.06.2015), zob. szerzej: Dangerous Brinkmanship: Close Military Encounters Between Russia and the West in 2014, "European Leadership Network Policy Brief", November 2014.

${ }^{30}$ Oczywiście, jeśli mowa o operacjach lądowych na dużą skalę, a nie obecności sił specjalnych, szkoleniowych, doradców itp.

${ }^{31}$ J. Czaputowicz, Bezpieczeństwo międzynarodowe. Współczesne koncepcje, Warszawa 2012, s. 119-120. Idąc tym tokiem rozumowania, J. Mearsheimer winą za wydarzenia na Ukrainie obarczył Zachód, który miał Rosję sprowokować jedynie do obrony jej żywotnych interesów i bezpieczeństwa. Zob. J. Mearsheimer, Why the Ukraine Crisis is the West's Fault. The Liberal Delusions That Provoked Putin, "Foreign Affairs", September/October 2014. 
Rosji) na hegemonii Stanów Zjednoczonych. Tym samym NATO stanowi dla Rosji zagrożenie, niemniej Rosja zdecydowanie bardziej koncentruje się na relacjach z państwami (zwłaszcza silnymi) niż z organizacjami międzynarodowymi..$^{32}$ Po drugie, NATO, jako organizacja międzynarodowa, zależna jest $w$ istocie od państw członkowskich i może podejmować tylko takie decyzje, na jakie członkowie ,pozwolą". Daje to przewagę Rosji: ośrodek decyzyjny jest scentralizowany, posiada spójną strategię i szereg instrumentów, służących rozbijaniu jedności Zachodu. Instrumentów tych może używać swobodnie, nie musi bowiem liczyć się z ograniczeniami, funkcjonującymi w zachodnich liberalnych demokracjach (takimi jak np. opinia publiczna, silne niezależne media itp.). Arsenał tych instrumentów jest różnorodny - od ekonomicznych (uzależnienie energetyczne, powiązania gospodarcze) po społeczno-polityczne (intensywne promowanie własnej wizji wydarzeń w przestrzeni informacyjnej, wspieranie rosnących w Europie w siłę radykałów).

Biorąc pod uwagę powyższe uwarunkowania, nie może dziwić kształt ostatniej rosyjskiej doktryny wojennej, ogłoszonej w grudniu 2014 roku. Sojusz Północnoatlantycki jest w dokumencie wprost wskazany jako zagrożenie dla Rosji, ponadto Rosja przyznaje sobie prawo do podejmowania kroków militarnych, jeśli uzna, że sąsiednie państwa prowadzą politykę, która ,zagraża interesom Federacji Rosyjskiej” - co jest w sposób oczywisty efektem wydarzeń na Ukrainie. Echem tych wydarzeń są także zawarte $\mathrm{w}$ doktrynie sformułowania, odnoszące się do "działań zmierzających do zmiany ustroju" i w istocie pozwalające na zaostrzenie kontroli społeczeństwa. ${ }^{33}$ Nową doktrynę Rosja określiła mianem „obronnej”, podczas gdy na Zachodzie nazwano ją , agresywną”. Rozbieżność ta potwierdza, że geopolityczne i historyczne uwarunkowania kultury strategicznej Rosji są inne niż w przypadku państw zachodnich - zarówno pod względem wizji państwa, jak i jego bezpieczeństwa oraz zagrożeń. Odmienne są również kultury strategiczne poszczególnych państw NATO, szczególnie państwa wschodniej flanki, które z racji uwarunkowań historycznych i w związku z polityką Rosji obawiają się o swoje bezpieczeństwo. Obawy te powodują rosnącą nieufność wobec sojuszu, nie tylko jeśli chodzi o realność militarnej pomocy NATO w przypadku agresji, ale nawet jeśli chodzi o samą wolę sojuszu, by pomocy udzielić. Obawy te nie są bezpodstawne - według sondażu Pew Research Center z czerwca 2015 roku w niektórych państwach sojuszu (Niemcy, Francja, Włochy) ponad 50\% społeczeństwa opowiada się przeciw udzieleniu pomocy militarnej sojusznikom w przypadku agresji Rosji - co oznacza faktyczną negację istoty sojuszu. Rozbieżności istnieją także w odniesieniu do tego, jaką politykę należy prowadzić w stosunku do Rosji. ${ }^{34}$

${ }^{32}$ D.P. Jankowski, T.K. Kowalik, Stosunki NATO-Rosja w nowym międzynarodowym środowisku bezpieczeństwa, „Rocznik Instytutu Europy Środkowo-Wschodniej”, red. T. Kapuśniak, 2010, z. 3, s. 104.

${ }^{33}$ Tekst doktryny: http://news.kremlin.ru/ref_notes/461.

${ }^{34}$ Zob. szerzej: K. Simmons, B. Stokes, J. Poushter, NATO Publics Blame Russia for Ukrainian Crisis, but Reluctant to Provide Military Aid, http://www.pewglobal.org/files/2015/06/Pew-Research-Center-Russia-Ukraine-Report-FINAL-June-10-2015.pdf, (dostęp: 11.07.2015). 
Ponadto, na szczeblu decyzyjnym NATO nie ma strategii działania - we wrześniu 2014 r. (tj. prawie 8 miesięcy po rozpoczęciu konfliktu na Ukrainie) generał Philip Breedlove przyznał, że sojusz nie jest przygotowany na scenariusz wojny hybrydowej ani nie ma przygotowanych metod działania na wypadek rozszerzenia przez Rosję zakresu tego typu działań na obszarze innych państw. ${ }^{35}$ Wynika to nie tylko z nowych jakościowo cech tego zjawiska, ale także, a może przede wszystkim, z rozbieżności stanowisk i interesów poszczególnych członków sojuszu.

\section{UKRAIŃSKIE DYLEMATY NATO}

Ukraina, biorąc pod uwagę instytucjonalną architekturę bezpieczeństwa, znajduje się w swoistej próżni bezpieczeństwa, rozciągającej się w Europie Wschodniej od Białorusi do Mołdawii i dalej na Kaukaz. Wydarzenia na Ukrainie destabilizują ten obszar, co niepokoi zwłaszcza państwa położone w bezpośrednim sąsiedztwie. Świadczy o tym chociażby fakt, że jednym z priorytetów, zawartych w Strategii Bezpieczeństwa Narodowego RP, jest wzmacnianie funkcji obronnej NATO i jego wschodniej flanki - właśnie w kontekście wydarzeń na Ukrainie. Nie oznacza to wszakże, że obawy te w równym stopniu są obecne we wszystkich państwach członkowskich sojuszu.

Sama Ukraina nie jest dla NATO priorytetem i zarówno władze, jak i społeczeństwo ukraińskie zdają sobie z tego sprawę. Ewentualna kwestia członkostwa Ukrainy w NATO jest poza dyskusją, przynajmniej w najbliższej dekadzie. I to mimo trwającej od lat 90. współpracy. W 1994 roku Ukraina przystąpiła do Partnerstwa dla Pokoju, w 1997 roku utworzono Komisję NATO-Ukraina, Ukraińcy uczestniczyli też w operacjach NATO (Bośnia i Hercegowina, Kosowo, Afganistan, Morze Śródziemne). We współpracy z NATO prowadzono operacje likwidacji min lądowych, amunicji i uzbrojenia, zgromadzonych w czasie zimnej wojny. ${ }^{36}$ Zacieśnianie współpracy zostało wyhamowane tak przez sytuację wewnętrzną Ukrainy, a zwłaszcza objęcie władzy przez Wiktora Janukowycza, jak i w wyniku postawy samego sojuszu, który na szczycie w Bukareszcie w 2008 roku faktycznie zamknął Ukrainie drogę do bliższej integracji, a w perspektywie być może członkostwa w sojuszu. Z powodu swojego geostrategicznego położenia Ukraina wciąż jest elementem rozgrywki geopolitycznej, która została „uruchomiona" $i$ której stawką jest przeformułowanie zasad pozimnowojennego porządku międzynarodowego. ${ }^{37} \mathrm{~W}$ takim ujęciu Ukraina jest swoistym poligonem, nie tylko dla Rosji, ale także dla innych podmiotów, które nie są tam explicite obecne.

${ }^{35}$ Breedlove: NATO Has Begun Shaping Rapid Response Force, http://www.atlanticcouncil. org/events/past-events/breedlove-nato-has-begun-shaping-rapid-response-force (dostęp 11.07.2015).

${ }^{36}$ Zob. szerzej: H. Shelest, NATO and Ukraine: In or Out?, "Caucasus International", vol. 4, no. 3-4, Winter 2014-2105, s. 55-64.

${ }^{37}$ Zob. szerzej: T. Kapuśniak, Ukraina jako obszar wpływów międzynarodowych po zimnej wojnie, Warszawa-Lublin 2008, s. 45-49. 
NATO, jak wspomniano, z powodu rozbieżnych interesów państw członkowskich, znajduje się w impasie decyzyjnym. Natomiast Rosja nie ma problemu z rozdrobnieniem ośrodka decyzyjnego i ma niewiele do stracenia - musi się odnaleźć w wielkiej grze. Stawką tej gry jest, między innymi, wzmocnienie własnej pozycji kosztem Zachodu. Jednak rywalizacja ekonomiczna z Zachodem (w tym wariancie rozumianym jako Unia Europejska plus Stany Zjednoczone) jest skazana na niepowodzenie, o czym decyduje struktura rosyjskiej gospodarki $i$ tendencje na globalnych rynkach surowcowych. Pozostaje płaszczyzna, w której Rosja posiada znaczący potencjał, know how i strategię działania - płaszczyzna militarna - w tym wariancie „naturalnym” zachodnim antagonistą jest NATO. Antagonistą, który nie stanowi znaczącego wyzwania, jeśli wziąć pod uwagę, że Europa nie stanie się potęgą militarną, mogącą równoważyć potencjał Rosji, a i europejska jednomyślność w sprawie sankcji przeciw Rosji jest na dłuższą metę niemożliwa do utrzymania. Konkurowanie z Zachodem w sferze militarnej nie oznacza otwartej konfrontacji zbrojnej, czego przykładem jest Syria: militarne zaangażowanie Rosji w Syrii przynieść może zyski polityczne w postaci utrzymania niestabilności na Bliskim Wschodzie (co nie jest korzystne dla Europy, np. ze względu na kryzys migracyjny), umocnienia przyczółka w tym regionie (i tym samym zabezpieczenia wyjścia na Morze Śródziemne), a także zysków wizerunkowych (,walczymy z terroryzmem" - w przeciwieństwie do Zachodu).

W efekcie Sojusz Północnoatlantycki stanął przed dylematem, dotyczącym działań wobec kryzysu ukraińskiego. Czy należy wspomóc Ukrainę militarnie? Czy zaostrzyć kurs wobec Rosji? Czy podjąć raczej działania koncyliacyjne? Czyim kosztem w takim razie? Jak utrzymać spójność polityczną sojuszu? Jak dotąd, w sprawie Ukrainy NATO uczyniło relatywnie niewiele. Jednak powołany po wyborach z 2014 roku rząd Ukrainy zapowiedział odejście od statusu państwa pozablokowego (ogłoszonego w okresie rządów Wiktora Janukowycza) i wznowienie starań o wejście do NATO. Po raz pierwszy też w historii państwa ukraińskiego społeczne poparcie dla wejścia Ukrainy do NATO przekroczyło $50 \%$. Abstrahując od tego, na ile te zapowiedzi znajdą odzwierciedlenie w rzeczywistości i biorąc pod uwagę skomplikowaną sytuację wewnętrzną Ukrainy oraz postawę samego NATO w tej kwestii, oznacza to, że Rosja musi utrzymać destabilizację Ukrainy (co zamknie jej drogę na Zachód, jak Gruzji). Wynika to ze zmiany sytuacji geopolitycznej - dopóki Ukraina balansowała między Zachodem a Rosją, ta nie reagowała gwałtownie, świadoma swoich wpływów kulturowych i ekonomicznych na Ukrainie oraz słabości wewnętrznej państwa ukraińskiego. Jednak po wyborze przez Ukrainę opcji zachodniej i po wydarzeniach na Majdanie Rosji nie pozostaje nic innego, jak kontynuować obrany kurs w polityce zagranicznej. Obecnie nie ma już mowy o koncepcji Noworosji ani nawet o „korytarzu" na Krym, ale wycofanie się z Ukrainy oznaczałoby porażkę i poważne problemy dla prezydenta Putina w polityce wewnętrznej. Bezprecedensowo wysokie poparcie, jakim się cieszy, w dużej mierze zależy bowiem od sukcesów w neoimperialnie prowadzonej polityce zagranicznej. Jeśli ich zabraknie, może 
to ze zdwojoną mocą obnażyć słabości wewnętrzne: archaiczną strukturę gospodarki, zapaść demograficzną, rozwarstwienie społeczne, dysfunkcyjność państwa w wielu dziedzinach. Już obecnie niskie ceny paliw i uniezależnianie się państw europejskich od rosyjskich dostaw surowców energetycznych (i w mniejszym stopniu zachodnie sankcje) doprowadziły do głębokiego spowolnienia rosyjskiej gospodarki, w tym także rosnącej niewydolności sektora zbrojeniowego. W żywotnym interesie Rosji pozostaje zatem dążenie do rozbicia jedności Zachodu, przy użyciu zarówno instrumentów ekonomicznych (utrzymanie zależności energetycznej państw europejskich), jak i polityczno-społecznych (rozgrywanie antagonizmów wewnętrznych i międzynarodowych w Europie). „Zamrożony” konflikt na Ukrainie jest tu doskonałym punktem wyjścia. ${ }^{38}$

Kryzys ukraiński stał się zatem testem spójności i wiarygodności NATO, bez których zasadność istnienia sojuszu jest wątpliwa. Tymczasem obecnie Europa jest podzielona w sprawie Ukrainy (co przekłada się także na stosunek do Rosji), a rozdźwięk pogłębia się, obejmując kolejne obszary, w ostatnim czasie problem napływu imigrantów. Rozbieżność, czy też niejednoznaczność, stanowisk państw Europy wobec Ukrainy znajduje swoje odzwierciedlenie w stanowisku sojuszu, który jedynie potępił działania Rosji (co z punktu widzenia Rosji nie ma żadnego znaczenia), ale nie podjął żadnych zdecydowanych działań, poza podjęciem decyzji o rotacyjnej obecności niewielkich jednostek sojuszu w państwach wschodniej flanki i poza kontynuowaniem operacji Baltic Air Policing. ${ }^{39}$ Pod znakiem zapytania stoi przyszłość relacji NATO z Ukrainą. Od ich kształtu i motywacji (pragmatyzm vs. wartości) będzie zależał kształt całego bezpieczeństwa regionalnego w Europie Wschodniej i w obszarze czarnomorskim. ${ }^{40}$ Sojusz winien sobie jednak zdawać sprawę, że odwrócenie się od Ukrainy oznacza jej radykalizację, czego symptomy są już widoczne.

Kryzys ukraiński postawił też Sojusz Północnoatlantycki przed kolejnym wyzwaniem: NATO przez długi okres skupiało się głównie na przygotowywaniu się do prowadzenia działań ekspedycyjnych out of area, co skutkowało m.in. obniżeniem zdolności do obrony terytorium traktatowego, która jest podstawowym celem istnienia sojuszu (i co znajduje swoje odzwierciedlenie i potwierdzenie w kolejnych koncepcjach strategicznych NATO). Obrona kolektywna, rozumiana jako obrona terytorium w przypadku ataku militarnego (konwencjonalnego bądź nuklearnego) zeszła na drugi plan, ustępując działaniom, związanym z zagrożeniami asymetrycznymi (terroryzm, przestępczość zorganizowana), cyberzagrożeniami i „eksportem stabilności”. Okazuje się jednak, że trzeba wzmocnić obronę kolektywną, nie tylko w wymiarze konwencjonalnych działań militarnych, ale na

${ }^{38}$ Czego przykładem rozgrywanie napięć etniczno-narodowościowych w Europie Środkowej i Wschodniej - między Polakami a Ukraińcami, Słowakami a Ukraińcami, Polakami a Litwinami, Łotyszami a Rosjanami itp.

${ }^{39}$ Która nota bene została w sierpniu 2015 r. zredukowana o 50\%.

${ }^{40}$ H. Shelest, op. cit., s. 64-67. 
wypadek działań hybrydowych. To wymaga szeregu szczegółowych analiz w odniesieniu do różnych scenariuszy, dotyczących nie tylko obszaru traktatowego. Za przykład może posłużyć Gotlandia - bałtycka wyspa, która należy do neutralnej Szwecji pozostaje praktycznie niebroniona. Jej ewentualne zajęcie przez rosyjskie siły specjalne formalnie nie stanowiłoby agresji wobec NATO, a jednocześnie byłoby tyleż łatwe, co strategicznie niebezpieczne - Rosja mogłaby kontrolować całe Morze Bałtyckie, co poważnie utrudniłoby, jeśli nie uczyniło niemożliwym, ewentualne przyjście z pomocą bałtyckim członkom sojuszu.

\section{WNIOSKI}

Jeżeli przyjmiemy, że ryzyko jest funkcją dwóch zmiennych o charakterze negatywnym - prawdopodobieństwa straty i jej wielkości ${ }^{41}$ to być może logika niezaangażowania operacyjnego była podyktowana nieadekwatnością zysków do strat dla sojuszu jako organizacji i poszczególnych członków. Nie oznacza to jednak, że ten proces decyzyjny został zamknięty. By odzyskać inicjatywę i jednocześnie zachować własną wiarygodność, sojusz musi zmierzyć się z ryzykiem i podjąć kluczowe decyzje. Najbliższą okazją będzie szczyt w Warszawie latem 2016 roku. Pozostaje pytanie, jakiej wagi będą to decyzje. W Newport po raz kolejny podkreślono obronę kolektywną jako priorytet sojuszu, niemniej decyzje podjęte w czasie tego szczytu można określić jako symboliczne: pułap 2\% PKB na obronność ma być osiągnięty dopiero za 10 lat (tymczasem niektóre państwa członkowskie nadal redukują swoje wydatki obronne), natomiast w kwestii zwiększonej, stałej obecności sił NATO na wschodniej flance (m.in. w Polsce) z powodu rozbieżności zdań między członkami sojuszu nie udało się wypracować jednoznacznego, zdecydowanego stanowiska. Kluczowym problemem jest ograniczona zdolność reagowania na nowe jakościowo zagrożenia ze strony Rosji - największe i najsilniejsze państwa sojuszu nie odczuwają bowiem bezpośredniego zagrożenia. ${ }^{42}$

Koniecznym wydaje się także podjęcie decyzji, dotyczących tzw. sytuacji trudnokonsensualnych - jak doprecyzować Artykuł 5, by stanowił on podstawę do działania w zmienionym środowisku bezpieczeństwa? Już nie tylko klasyczna agresja zbrojna nam zagraża (co nota bene stało się jasnym już w chwili zastosowania tego artykułu, po atakach z 11 września 2001 roku), ale także działania o charakterze hybrydowym - czego dowiódł konflikt ukraiński. Co należy uznać za naruszenie integralności terytorialnej państw członkowskich, stanowiące casus foederis? Ponadto, konieczne jest wypracowanie scenariuszy działań wobec dylematów przed jakimi stoi NATO: 1) co obecnie jest głównym zagrożeniem, na którym sojusz winien się skoncentrować: tradycyjne zagrożenia militarne czy także pozamilitarne

${ }^{41}$ P. Sienkiewicz, Analiza systemowa. Podstawy i zastosowania, Warszawa 1994, s. 208.

${ }^{42}$ W. Lorenz, Szpica NATO potrzebuje tarczy na wschodniej flance, „Biuletyn PISM”, Nr 15, 9 lutego 2015. 
i dotyczące politycznej stabilności? 2) w jaki sposób powstrzymywać Rosję przed agresywnymi działaniami? 3) jaki przyjąć model relacji z Rosją? 4) do jakiego stopnia akceptować działania Rosji w państwach trzecich (spoza sojuszu) oraz czy i jak podejmować przeciwdziałania? ${ }^{43} \mathrm{Z}$ punktu widzenia organizacji, będącej w założeniu sojuszem obronnym, fundamentalny dylemat decyzyjny odnosi się do zachowania spójności i takiego potencjału odstraszania, który, powstrzymując ewentualnych antagonistów przed przekroczeniem ,cienkiej czerwonej linii”, jednocześnie nie sprowokuje eskalacji wrogości, tudzież nie zainicjuje „,nowej zimnej wojny". Wewnętrzna spójność (i co za tym idzie, wiarygodność) sojuszu wymaga natomiast długofalowego zaangażowania państw członkowskich w budowę systemu obrony zbiorowej (jakim NATO wszak w założeniu jest). Kryzys ukraiński pokazał, że jest to dla sojuszu wyzwanie natury egzystencjalnej. Bo, jak napisał Andrzej Makowski jeszcze przed wydarzeniami na Majdanie: ,(...) nową dewizą NATO winno być obecnie 'każdy za siebie, a nikt za wszystkich'. Tym, co łączy dziś wszystkich członków NATO, jest już tylko skłonność do wyciszania problemów. Partnerom brak wspólnego stanowiska w kwestii, czym jest bezpieczeństwo w zmienionym świecie, jakie są zagrożenia i jak na nie reagować". ${ }^{44}$

Ryzyko (niepewność), towarzyszące strategicznym decyzjom, istnieje - ale brak działań, zdecydowanych, także może doprowadzić do eskalacji działań rosyjskich, która z kolei przyspieszy erozję NATO. Proces ten będzie tym głębszy, im bardziej państwa członkowskie będą patrzeć na Rosję przez pryzmat bilateralnych z nią relacji i interesów. Decyzje dotyczące strategii i przyszłych działań sojuszu muszą uwzględniać także Ukrainę, ponieważ pozostawienie jej na marginesie polityki NATO zagraża samemu sojuszowi. Zwięźle ujął to generał Wesley Clark: "If we lose Ukraine, NATO will be much more difficult to manage". ${ }^{45}$

\section{CRISIS IN UKRAINE AS A CHALLENGE FOR NATO}

Summary. The paper focuses on the Ukraine crisis as a decision making dilemma challenging NATO's cohesion and reliability. The challenge is determined both by internal (divergence of interests among the member states) and external factors (Russia's policy aiming at regaining superpower status by i.a. breaking the West's unity). In this view Ukraine is for Russia an instrument in a geopolitical game against the West, while for NATO it is a risk factor that demands strategic and long-term decisions.

Key words: NATO, Ukraine, Russia, risk, decision making

${ }^{43}$ O. Oliker, M. J. McNerney, L. E. Davis, NATO Needs a Comprehensive Strategy for Russia, RAND Corporation, PE-143-OSD, 2015, http://www.rand.org/pubs/perspectives/PE143, (dostęp 08.09.2015).

${ }^{44}$ A. Makowski, Czy możliwa jest nowa tożsamość NATO?, [w:] NATO wobec wyzwań..., s. $79-80$.

${ }^{45}$ General Wesley Clark: America's Global Strategy Begins With Ukraine, http://www. atlanticcouncil.org/blogs/new-atlanticist/general-wesley-clark-americas-global-strategy-begins-with-ukraine, (dostęp 11.07.2015). 